\title{
Poverty Reduction Policy Toward Strengthening Economic Society In Indonesia
}

\author{
Patta Rapanna/Ansar \\ Lecturer/Lecturer Makassar Bongaya Stiem Stim Yapim Maros, \\ South Sulawesi, Indonesia
}

\begin{abstract}
This type of qualitative research through penekatan Phenomenology, reduce the rate of poverty in indonesia, required a reliable and specific strategies, in addition the concept of Empowerment is good rather than by giving a number of cash once discharged continuously, but how Governments and perpetrators can upgrade the empowerment and capacity building of poor communities explore and always give his advocacy towards their problems, poverty reduction Programs will run effectively if there is a strong synergy between components of the nation include the Government, private, and community. The community must be constantly involved in the American, the preparation of, implementation and monitoring, so that hasilnyapun can be enjoyed by masayrakat itself because it is they who most know their needs. Government and private sector should give direction and support, but more important than that is the second stakeholders (Government and private) able and willing to create a business climate.
\end{abstract}

Keywords: empowerment, poverty, NGOs, strategies, service.

\section{INTRODUCTION}

The impact of poverty in Indonesia gave rise to various diseases in high risk groups such as pregnant women, nursing mothers, infants, children, and seniors. Since the economic crisis in 1997, the number of poor in Indonesia is increasing ". Poverty happens in Indonesia is causing low nutrition coverage, less health care, bad neighborhoods, and the cost of medical treatment does not exist. Due to illness, resulting in low productivity, low earnings and expenditure increases.

Poverty has indeed never cease and not get bored of destroying the ideals of society Indonesia especially the younger generation. The poverty of the already numerous "blinded" all aspects such as education. Most of the population of Indonesia because of economic limitations that do not support, by a small example that happened on the field a lot of children who dropped out of school because of debt, student of the SD SPP reckless suicide because of the shame is often charged by the school, the minors are working hard with the aim to give a rice for his family, and so on.
Now poverty has given the multi-faceted impacts ranging from a criminal offense, unemployment, health is compromised, and much more. Poverty can indeed cause a variety of problems, but for now the most important issue is how little kids are not at all capable of schooling as well as other children. That's the first problem to be solved by the Government because if the problem cannot be dealt with then it will emerge new problems even more. And also a lot of poor people affected by the disease, but they are difficult for medical treatment to the doctor because of expensive, although the Government has given the poverty card on them.

In addition to the above, a lot of impact that occurred caused by poverty are:

Community welfare very much and is very low in This means that by the presence of a high poverty level, many societies that Indonesia does not have sufficient income necessities of life of the community.

The death rate increased, this meant that the people of Indonesia a lot suffered from starvation or committed suicide because the actions are not strong in live in poverty.

Many residents of Indonesia who are starving because it can't afford to buy their food needs for everyday eating.

Not attending (a low level of education) it leads people in Indonesia do not have enough knowledge to get a job and do not have sufficient skills to earn income.

Crime rates are rising, Indonesia community so desperate to earn income in ways the crime because of the way that they either did not have the capital that is science and skill .

The problem of poverty is not only the issue of the nation of Indonesia. Poverty has become a global issue which every country felt interested parties to discuss poverty, regardless whether it was growing or developing countries. Developing countries in parts of Asia and Africa, strongly deal with the agenda of poverty reduction. Most of the people in the area still bear the poverty. While for developed countries, they were very interested in discussing poverty. Interest in it because of poverty in the developing countries have an impact on the stability of economic and their politics. 
In line with the efforts of pushing an increase in the well-being of the poor population in order to enjoy economic growth of increasingly qualified, then poverty reduction into national development priority. The main problem faced in poverty reduction is still a large amount of the population living below the poverty line. Despite the indications of the proportion of the poor population are likely to be declining, but the number of poor population in absolute terms is still high, in addition to poverty which is based on the size of income, poverty can be seen also from the community's ability to gain access to basic services, such as: 1) the poor quality of education caused by lack of educators and education in poor areas/remote, even in urban areas difficult to access education services caused fairly high education data. 2) Lack access to health services including family planning services $(\mathrm{KB})$ and reproductive health. 3) The lowest access of the poor to service drinking water. 4) Still weak institutional gender and children, especially in the regency /city level. 5) Still, legislation regarding gender and/or discriminating against women and awareness of children resulting in the low numbers of the gender-related development index (GDI).

\section{PROBLEM}

How can the implementation of poverty reduction in the strengthening of the Indonesian Economy?

\section{THE FOUNDATION THEORY}

\section{A. Economic Development}

Economic development cannot be simply interpreted development or industrialization. Economic development means development can more and more with the changes (growth plus change), because there is qualitative dimensions are quite important in the development process. Realize that in the process of construction of the always become impact of the unwanted by the public, such as in distribution gap of income, inequality and poverty.

Meier mentions economic development as, the process whereby the real per capita income of a country increases over a long period of time - subject to the stipulations that the number below an absolute ' poverty line ' does not increase, and that the distribution of income does not become more unequal (Meier, 1984:6). From this definition, it can be concluded that the indicator successful economic development is growth, the existence of equitable and increase welfare society (PEP-LIPI, 2001).

Sukirno (1985) stated that economic development is the suatuproses that caused per capita income of residents of something masyarakatmeningkat in the long run. On the basis of this definition, economic development is: (i) a process, which means merupakanperubahan that occur continuously, (ii) attempt to raise per-capita tingkatpendapatan, and (iii) the increase in per capita income was to be terusberlangsung in the long term (Prayitno, H and Budi Santoso, 1996).

Economic development needs to be viewed as a process supayasaling related and the relationship of interplay between factors that generate economic development can be seen. The next development of economic need to be viewed as the increase in income per capita, this is a reflection of the incidence of economic in prosperous improving to society. An indicator of the rate of growth of the State economic a one of them was shown with the growth rate of the Gross National Product or Produk Domestik.

Thus, development must be seen as a prosesmultidimensional that includes a variety of fundamental changes over the struktursosial, attitudes of society, and national institutions, besides the tetapmengejar accelerated economic growth, income inequality and handling, as well as poverty reduction. So in fact, that the construction of the must become an example, $\mathrm{n}$ changes of a society or a total adjustment of the overall social way system, without ignoring the diversity of individual and wanting basic needs as well as social groups is in it, to move forward toward a condition better all-round life, materially as well as spiritually (Todaro, 2004).

The accumulation of human capital has long been regarded as an important factor of economic development. The results obtained in the initial set of RegresiOleh because it was a bit disappointing when someone runs spesifikasion, CobbDouglas in Jess and Mark (1994) is function of standard production, which include human capital as factor the human capital accumulation, which failed to enter significantly the growth the economy, and even came in with a negative point estimate.

More and better education is a prerequisite for economic development all over the world. Education stimulates economic growth and improve people's lives through many channels: by increasing the efficient use of labor force, by increasing democracy (Barro, Thorvaldur in 1997, 2001) and thus create kondis.

Example, or model, the theory that successful economic growth adalahteori Robert Solow and Edward Denison (Robert, 1988) was developed and applied to the U.S. experience of the twentieth century. This theory would serve as a basis for further discussion in three ways: as an example of a form that agregatif theory useful should take, as a chance to explain what theory this form can tell us that other types of theory cannot, and as probability theory to economic development. 


\section{B. The Evolution Of The Economy}

Schumpeter (1942) in the James and JoAnn (2004) estimated the economy that emerged after World War II, with their emphasis on the giant companies are practicing economies of scale.

Simply reflect on what we have seen in the world to date. All over the world this is shrinking we have seen the power of entrepreneurship, the true wealth of Nations. In small, developing countries that we have seen entrepreneurship taking the role of Prometheus and bring the fire to fuel growth. In economics the previous communist countries we have seen entrepreneurship taking the role of Phoenix, the born-again ride from hive to rekindle the Fiery economic well being.

In our own history, we have seen a small band of refugees who fled the persecution of religious and economic construct the wilderness into a nation that covers the world with Yankee merchant ships and who grew up to be a leader in the Western world. We have seen the war torn, society is suppressed from Europe encourage their nation back from the brink of economic disaster into a dynamic, living members of a new world order. In all the stories we've ever witnessed on the stage of history, a single thread appears on every weaving, one constant emerged in every function, one aspect appears in every population: dreams of entrepreneurship. Let's eliminate the obstacles to the dream and watch brings our world into a brighter future.

Traditional economic development activities have involved local and State Government employees actively solicit and recruit great entrepreneurs through tax moratoriums, offer training and relocation assistance, infrastructure development or enhancements, or any one of a number of other incentive programs or proposals. This effort is expensive and has been highly praised in the past as the main source of job growth in a country or region (JoAnn and James, 2004).

\section{- Public Policy}

Public policy is the collective action that is realized through a legitimate Government authority to encourage, inhibit, prohibit or regulate the actions of private (individuals or private institutions). Public policy has two principal characteristics. The first, made or processed by government institutions or based on the procedure established by the Government (Hogwood and Gunn, 1988 in Simatupang, 2011). Second, the nature of the force or effect on private actions the public (public). For example, the fuel price policy is a public policy because it is made by the Government are forcing and can have an effect on the economic life of the inhabitants, the consumer mauun entrepreneur.

Public policy is what is selected by the Government to be done or not done. Carl Friedrich in Mariana (2010) sets forth that
ISSN No: - 2456 - 2165

the policy is potentially experiencing unplanned actions or activities proposed by a person, group, or Government in an environment where there is a certain hambatanhambatan (difficulties) and the possibilities (opportunities) where the policy is proposed in order to be useful in addressing it to achieve the objectives in question.

Luankali (Mariana, 2010) called the public policy making process include: 1) policy making as a political process. The theory of public policy makes it clear that the public does not understand the wisdom of making narrowly during the conversion process, but rather the saj is a series of activities that includes a series of events; 2) as policy making stage or series of activities. The public policy making process as a series of activities includes several stages such as: a) Drafting agenda (formulation of the problem); b) Policy Formulation (forecast); c) Adoption policy (recommendations); d) Implementation policy - the process output (monitoring); e) Assessment policy - outcomes of the process (of evaluation).

Public policy is a relatively new science because historically new emerged in the late decades of the 1960 's as an outstanding discipline within the scope of public administration as well as political science. In the meantime, analysis of public policy could arguably have long existed and can be traced the existence of human civilization. Since then, public policy is inseparable from the human life in the form of individual or micro-level context of macro level in the life of society and State (Wahab Bakry, 2008, 2010).

Aware public policy sense variations so vast and inevitable, because term policies attempt to explain in brief the various actions ranging from observing the issue or problem, formulate the formulation and monitoring and evaluation. This article refers to the notion that any legislation and regulations is the policy, but not every policy is manifested in the form of regulation. In the context of the notion of public policy, such as these, identified dimensions that are interlocked between public policy as the legal action is a legal choice, public policy hypotheses and public policy as a destination (Bridgeman and Davis, 2004 Bakry in 2010).

\section{- Transparency Of Public Policy}

Public transparency is the principle that guarantees access or freedom for everyone to obtain information about the Organization of the Government, i.e. information about policy, the process and its implementation, as well as the results achieved. Assumptions can be formulated, more transparent public policy, which in this case is a GRANT then supervision is performed by the Board will be increased because the society is also involved in overseeing public policies (Yulinda and Lilik, 2010 in Rudiyanto, 2012).

By luthfi, et al. (2003) in Werimon (2005) suggests, that the Government is said to be transparent if: (1) Government doing 
accountability to the people on a regular basis about the implementation of the duties of LEGISLATIVE/, (2) the Government is happy to provide information regarding the possible financial, (3) open Government always held a dialogue with the people either routinely or incidental on the entire product policies that have been made and she did. Mardiasmo (2003) mentions that the conceptual framework, in building transparency and accountability of public sector organizations needed four components consisting of: 1) the existence of a system of financial reporting; 2) the existence of a system of performance measurement; 3 ) Doing auditing the public sector; and 4) the proper functioning of public accountability channels (channel of accountability).

\section{A. the public service}

The concept of a public service by the Government are serving, trial, and cultivate the initiative and an active role in community development. Government services are given at every level of Government both at the Central Government, regions or villages. The concept of a public service that is conducted by a Government described by Munir (2002) in Kuswandi (2005) that: service to the community in General is defined as public service or the public service. IE as an activity undertaken by a person or a group of people with a grounding system through material factors, specific methods and procedures, in order to meet the business interests of another person in accordance with its rights.

In terms of execution of the service is done by the Government, further Munir (2002) (Kuswandi, 2005) explains that there are several factors to look for in supporting a service IE: consciousness of officials as well as officers who are engaged in service, the rules that became the cornerstone of the work of the Ministry, organization which is a tool as well as a system that allows the passage of the revenue service, mechanisms that can meet the minimum necessities of life, giver of Ministry officers skills and means in the implementation of the tasks of the Ministry.

\section{RESEARCH METHODS}

This type of research is a qualitative phenomenological approach through

\section{DISCUSSION}

The problem of poverty is a problem that needs to be dealt with crosscutting, sustainable and synergistic. This is due to the problem of poverty is a source of growing social problems emerge and others, such as abandoned children, beggars, the homeless, families settle down is not prostitute habitable, and many more. Therefore, the problem of poverty is an issue that should be addressed seriously by either the Government society, But so it must be admitted that, after some time the
ISSN No: - 2456 - 2165

Government regime change but adequate for the welfare of the people of Indonesia still not optimally. Fulfillment needs adequate social welfare need to continue to have to remember the majority of the people of Indonesia still has not yet reached the desired level of social well-being as for the handling of poverty not reached caused by:

\section{A. Inconsistent state governments in building the economic paradigm}

During the turn of the Government over the years, the Government still has not been able to realize the Economics of Pancasila for its people. Conceptually in law probably indeed we embraced the populist economic paradigms, which are adapted to the conditions of our society are agrarian and populist. But, in each of our economic policy, the Government still holds that with the rapid economic growth and creating economic stability, then the political well-being will be achieved. This is a paradigm of growth based on neoliberal economics. While on the other hand, in some programs, the Government is developing a policy demanding people's economy in the form of Small Medium Enterprises and so on, although the Government also expedited the establishment of mall and urban industrialization thus increasingly marginalize traditional markets as the economic base of the people. With urban industrialization condone (and is now venturing into the countryside), the Government is actually also contribute supporting high unemployment and social unrest in the community.

\section{B. the Politicization of issues of poverty and welfare sosia}

This condition still coloring our nation. So sometimes the community become apathetic to the nation's leadership for years. Because, oftentimes politicians-politicians we carry around welfare issues as a way to win power. While in reality landscape, there is no concrete steps which are executed exactly as his promises of campaign time.

Like for example, issues of economic development, the empowerment of underprivileged people, policy, education and free health services, all of which were impressed lip service, so so the leader, all the program does not run. So it's only natural, if each succession, poverty reduction programs are constantly changing the name even though the concept is the same. And the number of people miskinpun still does not change from year to year. In fact, many programs that stopped in the middle of the road. Example for example, PPK and P2KP program that replaced the PNPM Mandiri, then a P4K program ' in limbo ' since PPL resources are not met (as a result of running out of funds) so the fisherman-farmer mentoring is not running optimally, the OPK program was renamed again in 2001 to Raskin's policy. 


\section{C. poverty reduction Programs are still karikatif}

The granting of social assistance-assistance which is indeed necessary, provided that karikatif does not run continuously, as this will cause the dependence of the community to the Government. As a result, the community became can't empower themselves independently. The example program karikatif which is usually done by government institutions like LAZIS or BAZIS, which distributes the grant of tithes to the poor. Then the BLT program (direct Cash Assistance) that rolled out since 2005 up to now. The awarding of the BLT is still limited to fulfilling the basic needs of the community. Like people who are thirsty and hungry, then it should be fouled while with food. BLT also impressed into short-term programs.

\section{D. poverty reduction policies are not optimal}

Raskin and BLT is an example program that often gets a lot of criticism because of party management management is not good. Channeling Raskin and BLT is often not right on target. This goal due to data errors poor population used Government is not valid. People who have died are still recorded in the data, it is even capable of economically also guaranteed the BLT. Data discrepancies with reality often caused because bercokolnya the paradigm of ' project ' in each Department. There is no standardization of statistical data on poverty in Indonesia, so that each Department has its own standard of poverty and results between one Department with other departments that are different. Both the BKKBN, Social Department, and Depnaker and BPS each have different data. And is a great advantage for the Department may participate in serving the poor data on program BLT and Raskin. Although, it turns out that arriving at the field, a lot of chaos due to data errors.

\section{E. Empowerment Programs are not sustainable}

Group-based poverty reduction program community empowerment aims to develop and strengthen the capacity of poor communities to get involved in development based on the principles of community empowerment. The program's poverty reduction program in the group-based community empowerment have characterized as follows:

- the community was directly involved in development activities, ranging from the planning stages, execution, supervision and maintenance/preservation.

- management of the programs implemented through institutional community at the level of villages in a transparent and accountability.

- the Government provides mentoring personnel (technical assistance) are tiered from the starting level of the subdistrict, district/city, province and the central level
ISSN No: - 2456 - 2165

The scope of the areas of activity of the program on poverty reduction program group based community empowerment can be classified based on the supporting infrastructure development social economy at the level of villages, increased capacity (capacity building) for the community of miksin, loan capital for poor families trade micro and small through microfinance institutions (MFIs) are not a bank and not cooperative at the level of villages and districts, or social assistance/compensation for the family very poor/SHGS (the aged/elderly , toddler nutrition and improved scholarship), as well as the beneficiaries are community groups are categorized as poor.

F. The program's Poverty Penangulangan Empowermentbased Micro and small Economic

The program's poverty reduction empowerment-based micro and small economic is a program that aims to accelerate the economic development of the community with a local resource-based. Characteristics of the program on poverty reduction program group-based micro-economic empowerment and small is by granting the people's business credit to provide access to capital for small communities. Coverage on the poverty reduction program group barbasis the empowerment of small and micro credit channeling is an extension and reinforcement of institutional. The expansion of the distribution of credit in an effort to increase the amount of credits and debtors small and micro enterprises in the poverty reduction program group barbasis empowerment of small and micro businesses, local governments are expected to formulate the implementation of the extension of Credit To the people. Institutional strengthening in an attempt to improve the institutional micro is not a bank and not cooperative on the poverty reduction program group barbasis economic empowerment of micro and small business group Together, empowerment (KUBE), the Government is doing the Logging of small and Micro finance institutions (MFIs/KUBE) is not a bank and not cooperative, do mentoring towards microfinance institutions (MFIs/KUBE) that has not been incorporated in law, and did the coaching and supervision against microfinance institutions (MFIs/KUBE) beneficiaries program group empowerment-based poverty reduction micro and small economic are community groups almost poor activities its business on a micro scale and small and are judged eligible for assistance programs from the Government.

The Organization of the system of Government in a number of countries, including Indonesia, is likely to move towards decentralization. It happened as an attempt to reform and modernize the Government. Theoretically, decentralized authority handover and understood as a function of the national Government to the Government of sub-national or independent institutions (The World Bank Group, 2004). The basic idea of decentralization is the Division of authority in the field of decision making in organizations with a lower 
level. This understanding is based on the assumption that government organizations at the level of the actual conditions and needs to know from the local community, as well as unlikely the Government at the national level are able to serve and maintain the interest of the Community Affairs and so complex. Decentralization is also considered as an answer to the demands of democratization so great where local authorities expected more responsive than the Central Government's response to the various needs of the local community.

Governance is understood as the institution or institutions which organize and balance between the needs of the individual or the public will and public service items. Understanding it in line with modern social science terminology that defines local government as a functioning system in tandem with other systems in a larger system, where all these systems interact with each. Therefore, the alternative penangulangan program of poverty-based economic empowerment of micro and small Economic Ventures program particularly Along (KUBE) can be developed through local Government Social Service to support the progress of the economic growth of communities by increasing the capabilities of the members of the group in the FRENCH RIVIERA meets the needs - the needs of everyday life, with the aim of increasing family income, increasing the quality of the food, clothing, Board, health, level of education, can carry out religious activities and the increasing growth of other social needs. A number of programs and policies should be more memil changing the conditions of the target groups and the Government have a great investment - physical, financial, organizational, and policy and programs in the 2001 psychological that is being worked on, and it must be optimized.

This policy is governed by the Central Government, in this case is the Social Ministry and working with communities and agencies-agencies or other government institutions who were in the area of either the provincial government, the County and city. The achievement of poverty reduction policy through several programs such as the above, has strengthened the Foundation of the people's economy and self-reliance of the poor in particular and society in General.

It can even be said that the positive impact those policies affirming the desire of communities in responding to the idea of the new autonomous region started pelaksanaanya since 1999 (Act No. 22 of 1999 on local governance Act, Act No. 25 of 1999 regarding the financial balance of the Central Government and the regions, which were then replaced by law Number 32 Year 2004 and Act No. 33 of 2004). From the above programs certainly have alternate-side Kelamahan and Constraints
ISSN No: - 2456 - 2165

- The program is long-term in nature and cannot be measured in the current moment.

- The program is spreading and the public, there is no single criterion or suitability indices to measure what is accomplished.

- The program is vague and cannot be identified by the size of the rough or statistics.

- The fact that found about the lack of a difference people are recipients of the service and people who do not accept means that it was not intensive Program and indicate the need for more resources issued the program.

- The failure of a number of identifying a number of positive effects a program can make not suitable or bias in research, not on the program.

\section{POVERTY REDUCTION STRATEGY}

\section{A. Local community participation in policy making poverty reduction}

The policy of the implementation of the system of Government turn to desentralistik in teoritik should have a great impact to the development of poverty reduction programmes. Because in the system of decentralized local governments have full authority to conduct a program of empowerment of poor communities with the full involvement of local citizens. However, it turns out that many of the empirical findings the authors read from a variety of literature and research results that show that the local government is still not involving local communities in poverty reduction programs.

The basic idea of decentralization is bringing the country closer to the local community, among others, through participatory planning and improvements to public services. Participating local governments that generally knows better about the needs and choices of local residents rather than the Central Government. So as to allow the granting of public service relevant to local needs. Local government democratically elected generally more accountable and more responsive to the people and better engage popular participation in the political process. Decision making at the local level provides the responsibility, ownership and more encouragement to the perpetrators of the local, and local information can often identify ways of providing public goods. Decentralization is also relevant to the agenda of poverty reduction, for example identifying the decentralized approach towards poverty reduction into two alternatives, namely, technocratic and institution al. Technocratic stressed the target shape and investigate programs that try to steer resource-limited resources to the poor. With the approach of institutional records that the poor lack political power (powerless) and that inadequacies in administrative corruption and disease very annoying conducting government services. 
Therefore, poverty reduction requires development institutions, and changes in the political structure, improved governance, and change people's attitude towards the poor. Decentralization also facilitates technocratic forms that could improve the management of poverty reduction programs.

Can be inferred here that a Government that is accountable and responsive should involve the participation of citizens, which allows the occurrence process of poverty reduction. Participation itself could walk if there is minimum education, first, basic capabilities, information access and equality of gender. Second, people's empowerment at the local level.

Poverty reduction programmes should involve the full empowerment of the poor as objects. And P2KP PNPM actually conceptually already is nice, because it empowers the community independently. But in the involvement of the poor still less, is evident from the results of research PSKK GMU that involvement of the citizens and the poor is still not optimal. Therefore, programs need to do change learning strategies to prepare for a provision for the poor in order to be able to participate in the activities of the P2KP more intensively and optimally. So, the programs of the nonprofit capacity building needs to be done to increase the potential and capacities of the poor.

\section{B. Poverty reduction should be sustainable, continuous and independent}

Poverty reduction needs to be done in a gradual, continuous and integrated based on self-reliance, that is, the ability of the poor to help themselves. This means, the program should be poverty reduction based on increased ability of the poor to productive activities. So, are able to produce higher valueadded and greater income from an activity.

The efforts of meningkatkaan abilities generate added value, at least there should be an improvement of access to four things:

- access to resources.

- access to technology, i.e. an activity in ways and means of better and more efficient.

- $\quad$ access to the market. The resulting product must be sold to obtain added value. This means, the provision of the means of production and the improvement of skills must be balanced with the availability of the market on an ongoing basis

- $\quad$ access to sources of financing. Here the coordination and development of small credit systems reach the bottom needs to be continued and enhanced.

\section{Community-based reduction program}

This is important, because the apparatus region the most know problems and conditions of pockets of poverty in the
ISSN No: - 2456 - 2165

regions. The delegation is done by enhancing the ability of law enforcement and the public in the area itself. The closer the implementing programmes and activities with a target group, then the empowerment program will be more effective.

\section{Development of basic data in targeting poverty reduction}

Poverty reduction program which is karikatif like the help of rice poors and BLT is often the target of wrong. Therefore, to avoid this tejadi, then targeting methods need to be developed [16]. Because one of the keys to the success of poverty is the accuracy in the mentukan target group. Determination of target group also means the provision of data or information supporting the complete region about the potential and the characteristics of the poor population. The effectiveness of this method is specified by the completeness of the available information as well as support the implementing apparatus collectors and users of data.

For data, each Department is always different. The Government needs to determine which institutions will be designated to handle the data. In BPS, data collected through household Eonomi Masional national survey (Susenas), corporate data collected through the survey of activities of agricultural Companies, industrial companies and service companies, as well as the potential and the facilities of the village or community data compiled through Surveys of potential village (PODES).

\section{E. Developing The Economy Of The People's}

The most appropriate approach in addressing poverty is the people's economic development through a group approach, in the form of joint economic ventures. Integrated extension of the activities of undertakings attempted since the capital, mastery of production techniques, marketing results, until the surplus management effort. These efforts need to be supported institutional development social economy in the form of joint venture or cooperative.

F. Synergistic relationship and integrated between the Government and NGOs in programme preparation and mentoring society

NGOS are expected to cultivate self-reliance and developing participatory development at the ' grassroots ' level. The role of NGOs is generally implemented with some choices and stages: first, identify the needs of local groups and plan how the fulfillment of those needs. Secondly, formulate activities to achieve these goals. Third, produce, set up conditions and mobilize local resources or externally for rural development activities. Fourth, implement and manage activities. Cooperation between the Government and NGOs are expected to be able to increase the participation of the poor in the development process. 
There are several alternative forms of relationship between Governments with NGOs: first, the NGOS doing an activity was subsequently adopted and implemented by the Government. Second, NGOS acting as a pioneer or pioneer for the development of critical areas, where development programs have yet to reach. Third, NGOS complement government programs. Fourth, NGOS constantly cooperate with the Government in the empowerment program ranging from planning, implementation and monitoring stages right through to monitoring.

\section{CONCLUSION}

The existence of public policy the Government will give the influence of reinforcement in order to carry out the Government's program of governance, the governance improvement government programs are indispensable in creating jobs. To that end, the social Ministry coordination with institutions or agencies other related institutions is indispensable in order to convene the governance of Government in providing good services such as management of natural resources and the environment, job creation so that it occurs the process of absorption of labor in order to reduce the number of unemployed, moreover, in the implementation of governance must also be addressed to improve community participation in providing public services such as education and health. Cross-sectoral synergy is needed in the same poverty rate pressing together. in addition an increase in purchasing power of course adapted to the abilities of the community itself as a manifestation of the fulfillment of the basic needs of the community, in improving the governance of the programme, should be also done very corruption prevention, because it is highly related to the morality of the apparatus. Corruption prevention should banar-properly implemented for the improvement of morality, corruption eradication apparatus intended to suppress or eliminate the high cost of high economic investment increases, then there was a great increase in the production of which to improve the standard of living of the poor is ultimately able to cope with the problem of poverty.

\section{REFERENCE LIST}

[1]. Bakry Aminuddin (2010), "Kebijakan Pendidikan Sebagai Kebijakan Publik", Jurnal MEDTEK, Volume 2, Nomor 1, April 2010.

[2]. Blaxall, John. Governance and Poverty. Makalah dipresentasikan pada The Joint Workshop on Poverty Reduction Strategies in Mongolia, the world Bank, Ulan Bator, Mongolia, 2000.

[3]. Jess Benhabib, Mark M. Spiegel (1994), "The role of human capital in economic development Evidence from aggregate cross-country data", Journal of Monetary Economics 34 (1994).
ISSN No: - 2456 - 2165

[4]. JoAnn C. Carland dan James W. Carland (2004), "Economic Development: Changing the Policy to Support Entrepreneurship", Submitted to the Association for Small Business and Entrepreneurship, Western Carolina University 2004.

[5]. Kompasiana (2011), "Data Kemiskinan BPS Menampar Kebanggaan Sulawesi Selatan" http://regional.kompasiana.com/2012/01/07/data-kemiskinanbps-menampar-kebanggaan-sulawesi-selatan-428965.html.

[6]. Kuswandi Aos (2005), "Kesiapan Aparat Pemerintah Dalam Pelaksanaan Otonomi Daerah Pada Bidang Pelayanan Masyarakat (Studi Tentang Implementasi UU No. 32/ 2004 Di Kota Bekasi)", Jurnal Madani Edisi I/Mei 2005.

[7]. Mariana Dede (2010), "Otonomi Daerah Dan Inovasi Kebijakan”, governance, Vol. 1, No. 1, November 2010.

[8]. Maulida Elza Mutiara (2009), "Analisis Sektor Basis dan Potensi Daya Saing Pariwisata Kabupaten Tasikmalaya Pasca Otonomi Daerah", Departemen Ilmu Ekonomi Fakultas Ekonomi Dan Manajemen Institut Pertanian Bogor 2009.

[9]. Michael E. Porter (2000), "Location, Competition, and Economic Development: Local Clusters in a Global Economy", Economic Development Quarterly, Vol. 14 No. 1, February 2000 15-34.

[10].Prof. Shailendrakumar Uttamrao Kale (2004), "Global Competitiveness: Role of Supply chain Management", Conference on Global Competition \& Competitiveness of Indian Corporate, IIMK 2004.

[11]. Resya Nurul (2011), "Dasar, Pola dan Kebijakan Pembagunan Ekonomi”, resyapasha.blogspot.com/2011/04/dasar-pola-dan-kebijakanpembangunan.html.

[12]. Robert E. LUCAS, Jr. (1988), "On the Mechanics of Economic Development", Journal of Monetary Economics 22 (1988) 3-42. North-Holland.

[13].Rofiuddin Mohammad (2012), “Analisis Kinerja Keuangan Daerah di Pulau Madura Provinsi Jawa Timur Dalam Era Otonomi Daerah Tahun 2005-2009”, Jurnal Publikasi Fakultas Ekonomi Universitas Muhammadiyah Surakarta 2012.

[14]. Rudiyanto Dedi (2012), "Pengaruh Pengetahuan Dewan Tentanganggaran Terhadap Pengawasan Keuangan Daerah(APBD), Dengan Partisipasi Masyarakat dan Transparansi Kebijakan Publik Sebagai Variabel Moderating (Studi Empiris Pada Dprd Kabupaten Karanganyar)", Jurnal Publikasi Fakultas Ekonomi Universitas Muhammadiyah Surakarta 2012.

[15].Septina Pipih (2008), "Faktor-Faktor Yang Mempengaruhi Kesenjangan Pembangunan Ekonomi Antar Daerah di Propinsi Jawa Barat Periode 1996-2006", Program Studi Ekonomi Pertanian dan Sumber Daya Fakultas Pertanian Institut Pertanian Bogor 2008.

[16].Simatupang Pantjar (2011), “Analisis Kebijakan: Konsep Dasar Dan Prosedur Pelaksanaan (Policy Analysis: Basic Concept And Procedures)", Prosiding Seminar dan Ekspose 
Teknologi Hasil Pengkajian BPTP Jawa Timur ISBN 9793450-04-5.

[17].Thorvaldur Gylfason (2001), "Natural resources, education, and economic development", European Economic Review (2001).

[18].Wahyuni Sri (2008), “Analisis Kemampuan Keuangan Daerah Pemerintah Kabupaten Sragen Dalam Mendukung Pelaksanaan Otonomi Daerah", Fakultas Ekonomi Universitas Muhammadiyah Surakarta 2008.

[19]. Werimon Simson (2005), "Pengaruh Partisipasi Masyarakat dan Transparansi Kebijakan Publik Terhadap Hubungan Antara Pengetahuan Dewan Tentang Anggaran Dengan Pengawasan Keuangan Daerah (APBD) (Study Empiris Di Provinsi Papua)", Program Studi Magister Sains Akuntansi Program Pascasarjana Universitas Diponegoro November 2005. 